Institut für Makroökonomie und Konjunkturforschung Macroeconomic Policy Institute

\title{
Implications of insights from behavioral economics for macroeconomic models
}

\begin{abstract}
During the last 20 years, the importance of a number of behavioral features have been widely accepted within economics, and they are now regularly included in standard macro models. Where has this development led us? I argue that the insights from behavioral economics have led to important progress in our understanding of macroeconomic phenomena. One of the most important is the effect of fairness considerations on wages and employment relationships. Another important insight is that most or all individuals are affected by various behavioral features, which should be taken into account in the design of saving plans and pension schemes. A third insight is that plausible macro models provide large scope for important effects of sentiments and psychological factors. Future research should follow different routes, like incorporating behavioral features in standard models, improving estimated empirical models, and learning from case studies and historical episodes.
\end{abstract}

Keywords: Behavioral macroeconomics

JEL Classification: E2, E3, D8.

\footnotetext{
1 Department of Economics, University of Oslo,
} Mail: steinar.holden@econ.uio.no 


\title{
Implications of insights from behavioral economics for macroeconomic models
}

\author{
By \\ Steinar Holden ${ }^{1}$ \\ Department of Economics, University of Oslo \\ Steinar.holden@econ.uio.no \\ This version September 2012
}

\begin{abstract}
During the last 20 years, the importance of a number of behavioral features have been widely accepted within economics, and they are now regularly included in standard macro models. Where has this development led us? I argue that the insights from behavioral economics have led to important progress in our understanding of macroeconomic phenomena. One of the most important is the effect of fairness considerations on wages and employment relationships. Another important insight is that most or all individuals are affected by various behavioral features, which should be taken into account in the design of saving plans and pension schemes. A third insight is that plausible macro models provide large scope for important effects of sentiments and psychological factors. Future research should follow different routes, like incorporating behavioral features in standard models, improving estimated empirical models, and learning from case studies and historical episodes.
\end{abstract}

Keywords: Behavioral macroeconomics

JEL Classification: E2, E3, D8.

\footnotetext{
${ }^{1}$ I am grateful to John Driscoll, Gustav Horn, Kalle Moene, Ragnar Nymoen, Øistein Røisland and Sven Schreiber for useful comments to a previous version. The paper is part of the research activities at the centre of Equality, Social Organization, and Performance (ESOP) at the Department of Economics at the University of Oslo. ESOP is supported by the Research Council of Norway.
} 


\section{Introduction}

The last 20 years, assumptions and features from behavioral economics have been used more and more within macroeconomics. There are two main reasons for this change. First, an increasing body of research by cognitive psychologists and experimental economists has documented a number of systematic deviations in the thinking and decision-making of human beings compared to the traditional "economic man" assumptions. Thus, incorporating such features in economic models can no longer be criticized for being ad hoc. Secondly, it has become clear that standard economic models based on assumptions of optimizing behavior in many cases have problems with accounting for key real world observations. Hence behavioral assumptions have been included with the aim of making the model or theory better conform with the data.

The considerable evidence for "behavioral features" has been widely acknowledged within the economics profession. Moreover, behavioral features have been introduced in all parts of macroeconomics. Where has this development led us? Which assumptions should one now make when analyzing macroeconomic questions? This is the topic of the present paper. The aim of the paper is to provide a selective survey of the implications of insights from behavioral economics for macroeconomic models.

As we go along in the paper, I will argue that the insights from behavioral economics have led to important progress in our understanding of macroeconomic phenomena. We can now better explain important aspects of real world behavior than we could with the more restrictive theoretical framework of the past. A number of behavioral features are now regularly included in more standard macro models. This has improved the explanatory power of the models. However, the approach is not without problems. Even if there is considerable evidence for certain behavioral features, it is more difficult to know which specification is appropriate. For example, while there is strong evidence for inertia in consumption behavior, it is less clear whether the inertia should be viewed as habit formation, rule-of-thumb consumption, or other alternatives. Another key problem is to distinguish between behavioral features and other deviations from the standard economic model, like financial frictions, limited information or agency problems. For example, it may be difficult to distinguish between myopic consumption behavior and the effect of credit constraints. Thus, there is a need for more research on how behavior is affected by the external circumstances, to guide the choice of specification. More generally, research should follow different approaches: while implementing behavioral features in standard models are useful despite the difficulties, economists should also use estimated models as well as learn from case studies and historical episodes.

Given the widespread impact of behavioral economics on macroeconomics, it has been necessary to narrow the focus somewhat. I will discuss consumption, labor, inflation, expectations, and macroeconomics models, neglecting issues related to finance, growth and happiness. I will however include a brief discussion of asset market bubbles, because of the close association with macroeconomic fluctuations. Within each topic, I will discuss key 
innovations based on behavioral assumptions, as well as compare with non-behavioral alternatives. Regrettably, space constraints will imply that the presentation will have to be selective also within the topics that are covered.

The rest of the paper is organized as follows. In section 2, I provide a brief overview of important deviations from the economic man assumption that have been established in research by cognitive psychologists and experimental economists, and which form the basis of the behavioral impact on macroeconomics. The following 8 sections proceed to discuss various parts of macroeconomics. Section 11 concludes.

\section{Behavioral deviations from the economic man assumption ${ }^{2}$}

Most deviations from the economic man assumption can be grouped in one of three categories, depending on whether they relate to limited cognitive abilities, fairness and social norms, or preferences and self control.

\subsection{Limited cognitive abilities}

In the standard approach, agents treat information in a rational manner. Information may be imperfect, perhaps because it is costly to obtain, but the information that is available is treated in an optimal way. Yet a lot of research documents how agents often take a heuristic approach to complex situations, where they simplify so that the situation is easier to grasp. In most cases, this is rather useful, but occasionally it involves systematic and severe errors. There are several related types of errors, see Rabin (2003).

- Heuristic judgment and choice under uncertainty. Most people do not evaluate uncertain projects in an appropriate statistical manner. Very low probability events are often neglected, low probability events are overweighted, while high-probability events are underweighted. Small samples are viewed as much more representative of the underlying population than what is reasonable (law of small numbers), while they attach too little weight on prior information (base-rate neglect). When there are several pieces of information, partly conflicting, agents have a tendency to put more weight on information that is more memorable and salient (memorable evidence overweighed). Initial, often irrelevant information might have a strong effect, e.g. when an initial very high price given by the vendor pushes the sales price up (anchoring).

- Confirmatory bias, that is, when people have formed a hypothesis, they are reluctant to give it up. Subsequent evidence is viewed in light of the existing beliefs, and often interpreted as supporting the existing beliefs. Strikingly, experiments have shown that in situations where two groups have been given different information, and thus have

\footnotetext{
${ }^{2}$ This part of the paper draws heavily on Rabin (1998 and 2003), Bowles (1998), Fehr and Schmidt (2002) and Akerlof (2002).
} 
different opinions, when they are given new evidence, both groups interpret the new evidence as strengthening their own opinion.

- Framing - that two logically equivalent statements of a problem lead decision-makers to choose different options. This feature is well-known to marketing personnel - it is not a coincidence that firms give discounts to some age groups, as retirees, children, students, etc, rather than charge an additional fee for the other age groups.

- Overconfidence - that many individuals have an exaggerated view of their own abilities (see e.g. De Bondt and Thaler, 1985). Burks, Carpenter, Goette and Rustichini (2009) provide evidence indicating that 20 percent of the participants are less able than they believe, or at least that there is a 20 percent "overconfidence gap", e.g. 40 percent overconfident and 20 percent underconfident.

\subsection{Fairness and social norms}

A large body of research has documented a number of systematic deviations from the economic man- assumption that human beings are only motivated by their material selfinterest, see Fehr and Schmidt (2002) for a discussion, empirical evidence and further references.

Social preferences imply that agents' utility also depends on how much other players receive. This may take several different forms

- altruism (utility is increasing in the well-being of others)

- relative income and envy (utility is increasing in the income relative to others)

- inequity aversion (agents dislike inequality, even if favourable to themselves)

Intention-based reciprocity implies that agents care about the intentions of other players, and not only the distributional consequences. Thus, agents often

- return "good with good" (e.g. they cooperate if others cooperate), and they

- return "bad with bad" - experiments show that many agents are willing to take revenge on what they view as unfair behavior, even if it is costly to themselves

Interestingly, the experiments document large and persistent difference among the participants, where a large share reveal social preferences and intention-based reciprocity, while other participants behave according the traditional assumptions of pure material selfinterest. Social preferences and reciprocity can be viewed as two related types of concerns for fairness. Human beings do care about whether a situation is fair, both when it comes to the outcome and the process, and this may affect their behavior in important ways. 
Social norms may be defined as opinions people have as to how they and others should behave, or possibly how they and others should not behave, see Akerlof (2007) for a further discussion of the importance of norms for macroeconomics.

\subsection{Preferences and self-control}

Other research shows a number of features that are inconsistent with the view that agents maximize a stable preference function.

- Hyperbolic discounting - In the traditional approach, individuals discount at a constant rate, so that the difference between today and tomorrow is proportionally the same as the difference between one year, and one year and one day. Yet studies show, not surprisingly, that individuals are much less patient in their choice between today and tomorrow than when it comes to choices advanced further in the future.

- "Isolation error" - agents view choices as separate events, without taking into consideration the effect on the overall outcome. One consequence is that agents are averse to small-scale risk, even if the risk as to the total wealth is negligible.

- Endogenous preferences - in many situations, the preferences of the people concerned are affected in surprising ways. For example, studies show that paying people for a task that they might willingly do, might reduce their motivation for the task.

Reference based preferences imply that agents' utility depend not only on the current situation, but also on the current situation relative to a reference level, often given by recent history. The two main forms are (Tversky and Kahneman, 1991; Rabin, 2003)

- Loss aversion: people are more averse to losses relative to their reference level than they are attracted to the same-sized gains

- Diminishing sensitivity: the marginal change in perceived well-being is greater for changes that are close to reference level

Loss aversion is a key part of prospect theory (Kahneman and Tversky, 1979), and gives rise to the endowment effect, which describes the feature that once a person possesses a good, he values it more.

\section{Consumption behavior}

One of the areas where behavioral economics have had most impact, is household consumption. In this area, standard theory has been unable to explain key aspects of actual behavior. According to the permanent income hypothesis, consumption should be a purely forward-looking variable, depending on the net wealth of the consumer, including expected future labor income. Thus, consumption should respond instantaneously to new information 
about expected future income, but be much less responsive to changes in current disposable income, in so far this do not involve information about future income. However, empirical evidence shows that consumption respond much less to news, and that as result, consumption exhibits "excess smoothness" (Campbell and Deaton, 1989).

The main behavioral explanation for sluggish consumption and excess smoothness is habit formation among consumers, see e.g. Pollak (1970), Abel (1990) and Fuhrer (2000). Habit formation may arise from the endowment effect, see Loewenstein and Adler (1995). The existence of habit formation has been widely accepted, and the research has also shown that it has important implications also for other economic issues, like the equity premium puzzle (Constantinides, 1990). Fuhrer (2000) finds that including habit formation, in the sense that consumers' utility in part depends on current consumption relative to past consumption, improves the empirical relevance of standard models for monetary policy. Thus, in most of the so called Dynamic Stochastic General Equilibrium DSGE models used to analyze monetary policy today, one assumes habit formation among the households (see section 10 below).

Ljungqvist and Uhlig (2000) show that if utility functions exhibit the "catching up with the Joneses" - feature, so that if others consume more today, our representative consumer will experience a higher marginal utility from an additional unit of consumption in the future, optimal tax policy is pro-cyclical. The idea is that in booms caused by a positive productivity shock, consumption will be higher than the socially efficient level (the economy is "overheated"), as consumers do not take into account the negative externality on others. Thus, in booms, taxes should be raised to dampen the "overheating" of the economy.

While habit formation plays a strong role in much of the recent research in macro economics, the empirical evidence is mixed. Dynan (2000) finds no habit formation among US households, while Alessie and Teppa (2010) find evidence in favor of habit formation for Dutch households, but the magnitude is rather small. Fusaro and Dutkowsky (2011) analyze consumption behavior on the basis of checking accounts for US households, and the results give little evidence for habit formation. Rather, the authors interpret their findings as evidence in favor of "rule-of-thumb" consumption of the type suggested by Campbell and Mankiw (1990), with liquidity constraints. Overall, one may question whether the persistence observed in consumer behavior should be taken as evidence of habit formation, or whether it reflects other sources of inertia. For example, Akerlof (2007) emphasises the role of norms as a key factor behind consumption decisions.

From a policy point of view, a key aspect of consumption behavior is the response to tax changes. In a survey of the evidence, Auerbach, Gale and Harris (2010) conclude that household consumption respond more vigorously to tax changes that are plausibly expected to be longer-lasting than to those expected to be shorter-lasting, consistent with the standard optimizing behavior. However, some studies show that the way tax cuts are described may affect behavior, suggesting a role for framing and default specifications. Hsieh (2003) finds that the source of income fluctuations matters. He shows that while households in Alaska use 
a considerable part (30 percent) of a income tax refund on non-durable consumption, the same households smooth their payments from the Alaska Permanent Fund, suggesting that households understand the nature of the payments from the Permanent Fund. Hsieh interprets the difference as evidence in favor of bounded rationality, in the sense that household treat large and transparent income changes consistent with the permanent income hypothesis, while smaller or less transparent income changes to a greater extent are used for current consumption.

In a survey of empirical consumption studies, Jappelli and Pistafari (2010) conclude that liquidity constraints seem to be play an important role for why consumption responds to anticipated income changes, because consumption appears much less responsive to anticipated income declines, e.g. after retirement, when liquidity constraints have little bearing. There is also evidence of considerable heterogeneity in consumption behavior among income groups, which is consistent with liquidity constraints being more important for lowincome and low-education households. Overall it seems reasonable to conclude that both behavioral features as well as credit constraints shape consumption behavior, although the importance of each factor remains open.

\section{$4 \quad$ Long-term saving}

Long term saving decisions is another field where there is a discrepancy between traditional economic theory, which holds that savings decisions are optimal, and empirical evidence. An alternative and popular formulation based on a behavioral foundation is that consumers exhibit hyperbolic discounting, according to which there is a systematic preference for the present moment (Phelps and Pollak, 1968; Ainslie and Haslam, 1992). The formal representation is often in the quasi-hyperbolic form used by Laibson (1997), where the utility function can be represented by

$$
u\left(c_{t}\right)+\beta \sum_{i}^{\infty} \delta^{i} u\left(c_{t+i}\right)
$$

where $0<\delta<1$ is the discount factor and the parameter $\beta \leq 1$ characterizes the consumer's bias for the present. A consumer who discount hyperbolically $(\beta<1)$ rather than exponentially $(\beta=1)$ may exhibit time-inconsistent behavior (self-control problems) in the sense that $\mathrm{s} / \mathrm{he}$ systematically may prefer to reverse earlier decisions.

The time-inconsistent behavior that is implied by hyperbolic discounting involves difficult conceptual problems as well as important policy implications. Drawing upon earlier work by Ainslie (1992) and Schellling (1984), Bénabou and Tirole (2004) show that there is a conflict between the individual's successive "temporal selves", and that the individual may try to 
commit himself to specific actions that will not be chosen voluntarily at a later stage. ${ }^{3}$ Laibson, Repetto, and Tobacman (2003) argue that consumers appear to be of two minds; their large, voluntary, primarily illiquid retirement accumulations are consistent with a discount rate of 5 percent, while their frequent credit card borrowing is consistent with a discount rate of 18 percent.

Hyperbolic discounting generally gives rise to undersaving, and Laibson, Repetto, and Tobacman (1998) report that 77 percent of the respondents in a study of individuals between twenty-nine and forty-seven say that they save too little. Other studies, like Lusardi (2009), show that a large share of households do not plan for retirement, do not understand the basic concepts of financial decision making, and are not getting any help. Lusardi also shows that the lack of planning matters for US households, as nonplanners save less, implying that they hold about 20 percent less wealth close to retirement. Choi, Laibson and Madrian (2011) show that in the average firm, more than a third of the workers contribute too little in $401(\mathrm{k})$ pension plans, even if the firm would have matched their contribution, and even if the workers could subsequently withdraw savings without any penalty. Thus, workers are forgoing arbitrage profits that average 1.6 percent of their annual pay, or \$507. Educating the employees did little to improve the problem. Laibson (2009) concludes that while one should try to promote financial literacy, other measures are also important. In particular, Laibson emphasizes the power of default options, referring to studies showing how this may increase savings (as Madrian and Shea, 2001, who find 401 (k) participation is significantly higher under automatic enrollment)

A good example of the potential effect of intervention is the "save more tomorrow" program designed and tested by Thaler and Benartzi (2004). In this program, employees were asked if they would increase their $401(\mathrm{k})$ contribution rates at the time of their next pay rise, implying that the increase in savings would not involve a reduction in the pay net of savings.

Employees who sign up for the program remain enrolled until they reach the maximum contribution rate or they opt out. The results showed that 78 percent enrolled the plan, and virtually everyone ( 98 percent) remained in it through two pay rises, implying a dramatic increase in contribution rates, from 3.5 percent to 11.6 on average over the course of 28 months.

Research based on various forms of hyperbolic discounting has thus proved useful in the design of real-world saving plans. However, on the conceptual side, key issues are still unsettled. While the evidence is strong that people's choices are inconsistent with the standard formulation with exponential discounting, it is not clear which formulation is the appropriate. Benhabib, Bisin and Schotter (2010) present experimental evidence suggesting that the present bias in the preferences are better characterized by a fixed costs associated with waiting, rather than variable cost implied by equation (1). Rubinstein (2003) is more critical to the interpretation of the evidence. He presents experiments suggesting that a decision

\footnotetext{
${ }^{3}$ See Burger, Charness and Lynham (2009) for recent evidence on different models of willpower.
} 
making procedure based on similarity relations provide a better explanation of the data than does the assumption of hyperbolic discounting. Studying adult Danes, Andersen, Harrison, Lau and Rutström (2011) find no evidence for quasi-hyperbolic discounting.

\section{$5 \quad$ Labor market and wage setting}

Insights from behavioral economics have had profound impact on our understanding of several labor market issues. Most importantly, perhaps, is the question of wage rigidity, where there is extensive evidence showing that wages are rigid, yet standard models have had problems with explaining this feature. In traditional neoclassical economics, labor is just an ordinary good, and the wage is just an ordinary price. Thus, the firm always benefits from paying the lowest possible wage that is sufficient to hire labor of the desired type and quality. In contrast, efficiency wage theories hold that workers' productivity depends on the wage that is paid. If workers find that they are paid too little, relative to some reference level, this may have a negative effect on their effort and productivity. In the "gift-exchange" theory of Akerlof (1982), firms give workers above market-clearing wages, and workers reciprocate by providing higher effort. In Akerlof and Yellen (1990) workers' effort depends on whether they find that the pay is fair. Whether the wage is found to be fair, may also depend on how it relates to social norms for what the pay should be (see e.g. Akerlof, 2007). ${ }^{4}$

There is now strong support for the existence of fairness concerns and related effects. One important example is Fehr, Kirchsteiger and Riedl (1993); see also Brown, Falk and Fehr (2004). They conduct an experiment to explore a two-player game illustrating an incomplete employment contract. The game occurs only once for each employer-worker pair, in the following way: The employer offers a wage and requests a certain level of effort from the worker. The wage is binding, but the requested effort is not enforceable. Workers can accept or reject the wage offer, and, upon acceptance, decide their effort. The employer's profit is equal to returns generated by the effort, minus the wage payment, while the worker's payoff is equal to his/her wage minus cost of effort. The experiments show a clear link between wage and effort, as workers who are paid more, on average provide more effort. However, there are huge differences across subjects: while there are many fair-minded workers who respond to a higher wage, there is also a substantial share of workers who do not.

The results change considerably in experiments with repeated interactions for each employerworker pair. With repeated interactions, also selfish subjects have an incentive to cooperate, as this may give them higher payoff in subsequent rounds. Several studies show that such reputation effects can be sufficiently strong to sustain high levels of efficiency, even under adverse conditions (Fehr, Brown and Zehnder, 2009). Also field evidence shows that "wage gifts" can lead to higher efforts by workers, see Fehr, Goette and Zehnder (2009).

\footnotetext{
${ }^{4}$ Efficiency wages may also be justified on the basis of asymmetric information, as in the shirking model of Shapiro and Stiglitz (1984), where firms pay high wages to reduce workers' incentive to shirk.
} 
The importance of the labor-management relationship is also borne out by the study of Krueger and Mas (2004), who examined the quality of Bridgestone and Firestone tires produced in different plants. They found that a labor strife taking place after the company had announced lower wages for new hires and changed shift rotations unfavorably, had a significant negative impact on the quality of the tires. Similar results have been found after a labor dispute at Caterpillar, a manufacturer of construction equipment and vehicles, see Mas (2008). The evidence also shows that when employers' actions are considered unfair, the negative effect is stronger than the corresponding positive effect when the actions are thought to be fair, see Fehr, Goette and Zehnder (2009).

If workers reduce effort if they find that the wage is unfair and too low, firms may abstain from reducing wages even if external circumstances might imply lower wages. Akerlof and Yellen (1990) use this mechanism to explain the existence of involuntary unemployment. Traditional economic theory implies that unemployment would lead to lower wages, reducing supply and increasing demand, thus eliminating unemployment. However, as argued by Akerlof and Yellen, efficiency wage effects may prevent the reduction in wages, implying that wages remain above the market clearing level, thus causing involuntary unemployment.

Another possible implication of fairness considerations is the existence of internal and external labor markets, where workers may seem insulated from outside labor market conditions once they are employed in a firm. Kahneman, Knetsch, and Thaler (1986) provide evidence that in judgment about fairness, new workers compare the firm's offer to what they could otherwise earn in the labor market, while incumbent workers compare with the existing wages in the firm. This may explain the empirical fact that wages are rigid downwards (see e.g. Bauer, Bonin, Goette and Sunde, 2007, and Holden and Wulfsberg, 2009, for evidence of downward real wage rigidity; downward nominal wage rigidity is discussed in section 6 below), and it may also explain the importance that relative wages are considered to be fair within the firm, see e.g. Bewley (1999). French, Kubo and Marsden (2002) analyze evidence from a survey on performance-related pay in the British public sector services. They find widespread de-motivating effects arising from difficulties of measuring and evaluating performance fairly.

Falk, Fehr and Zehnder (2006) show that fairness considerations may also be important for the effect of minimum wages. Traditional economic theory implies that minimum wages hurt employment, as the rise in wages lead to less demand for labor. However, a number of empirical studies show that the effect in many cases may be zero or even positive (e.g. Card and Kreuger, 1994), which would be the case if the firm has some monopsony power, implying that labor demand may increase if the wage is pushed down exogenously. Falk, Fehr and Zehnder undertake a laboratory experiment suggesting that minimum wages may have a strong upward effect on reservation wages, and thus also affect workers' perception of what a fair wage should be. This may push the actual wage up above the minimum wage, and the effect may last also if the minimum wage is abolished. 
Recently, there has been growing literature discussing whether wage rigidity based on social norms is the explanation of the strong cyclicality of unemployment and vacancies over the business cycle. Shimer (2005) showed that the standard search model predicted a much too low volatility in unemployment as compared to data, while Hall (2005) pointed out that if wages were rigid due to the existence of social norms, the model would be able to explain the empirical facts. However, other authors have been skeptical towards this explanation, arguing that wage rigidity for existing employees would not affect hiring decisions if the hiring wage were flexible. Thus, among others Pissarides (2009) argues that wages are flexible for new hires, implying that wage rigidity is not the explanation for the strong cyclicality of unemployment. Pissarides proposes a model with a fixed matching cost, which explains strong cyclicality of unemployment without wage rigidity.

\section{A multiplicity of equilibria}

A key feature of mainstream macroeconomic models is the existence of a unique long run equilibrium. To many economists, this feature is a great advantage, as it yields clear predictions. Other economists are more skeptical, and argue that plausible deviations from the restrictive standard assumptions generate a multiplicity of equilibria. In line with this, the existence of a unique equilibrium has been challenged in a number of contributions based on behavioral assumptions.

Bhaskar (1990) considers the implications if workers are concerned about fair treatment, in the sense that they care disproportionately more about being paid less than other workers than they do about being paid more than other workers. This assumption can be defended by evidence suggesting that workers' effort is harmed if they are paid less than the "norm" (Akerlof, 1984), or if workers are loss averse (Kahneman and Tversky, 1979). Bhaskar shows that when the fair treatment assumption is incorporated into a standard wage bargaining model, it implies that there is a range of equilibrium wage growth rates, for which each wage setter will aim for the same wage growth as set by the others. Intuitively, workers will demand high wage growth if others get high wage growth, and low growth if others get low, implying that both alternatives are possible in equilibrium. The range of equilibria for the wage setting implies that there also is a range of equilibria for aggregate output. All output levels within the range may persist at a permanent basis. Furthermore, if e.g. a large negative shock has pushed the economy to the lower end of the range, an expansionary monetary policy moving the economy to the upper end of the range will in fact involve a permanent increase in aggregate output. Lye, McDonald and Sibly (2001) find empirical support for the existence of a range of equilibrium unemployment rates in Australia.

Other contributions link the possible multiple equilibrium output to the rate of inflation. Akerlof, Dickens and Perry (1996) argue that wages are rigid downwards in nominal terms, due to the notion that employees, and in some cases also employers, think that nominal wage cuts are unfair; see Bewley (1999) and Dickens et al (2007) for additional evidence of 
downward nominal wage rigidity. ${ }^{5}$ Akerlof et al (1996) follow Tobin (1972) in pointing out that the combination of very low or zero inflation and downward nominal wage rigidity may lead to increased wage pressure, and thus also an increase in equilibrium unemployment. In this situation, an expansionary monetary policy allowing for higher inflation may involve a permanent increase in aggregate output.

Akerlof, Dickens and Perry (2000) take a slightly different approach, arguing that wage and price setters treat inflation differently from what most economists assume. First, when inflation is low, many people ignore it. Second, workers view nominal wage increases as a sign that they are appreciated, without taking into account that nominal wage increases also reflect a general rise in wage and price levels. More specifically, Akerlof et al. consider a model where workers' effort depends on their wage relative to a reference level. When inflation is low, near-rational firms and workers do not take it into account when updating their reference level, implying that wages are increased by less than they should. Thus, when inflation is low but positive, wage pressure is reduced, and equilibrium employment increased.

When inflation is high, however, it will be much more costly to neglect inflation. Thus, nearrational wage and price setters will take inflation fully into account when it is high. Hence, the reduction in wage pressure induced by inflation vanishes when inflation is high. Again, the upshot is that some inflation allows for higher equilibrium output than zero inflation, even if this latter explanation also implies that high inflation is associated with the same (low) output level as zero inflation.

While the detailed assumptions vary in the three stories above, the basic policy conclusion is essentially the same: a tight monetary policy may have a permanent negative effect on the economy by pushing output down to a low equilibrium level. This conclusion is consistent with the analysis of Ball (1999), who compares the monetary policy of North American and European countries in the 1980s and 1990s, and concludes that the tighter monetary policy in several European countries lead to long-lasting higher unemployment.

A multiplicity of equilibria may also arise from other, non-behavioral sources, like search complementarities (Diamond, 1982) or increasing returns to scale (e.g. Benhabib and Farmer, 1994). However, whenever there is a multiplicity of equilibria, there is room for effects of beliefs and sentiments, which may decide which equilibrium prevails. In several papers (see

\footnotetext{
${ }^{5}$ Downward nominal wage rigidity is often mentioned as an example of money illusion, where agents confuse real and nominal variables, see e.g. Shafir, Diamond and Tversky (1997).

${ }^{6}$ Downward nominal wage rigidity can also be justified as the result of a nominal wage contract that can only be changed by mutual consent, consistent with the institutional setting in most OECD countries, see MacLeod and Malcomson (1993) and Holden (1994). As argued by Holden (1994), the fairness and contract arguments are complementary, in the sense that fact that the nominal wage is given in the contract, is likely to strengthen the feeling that it is unfair to cut the wage.
} 
e.g. Howitt and McAfee, 1992), the fluctuations are caused by random waves of optimism and pessimism, along the lines suggested by John Maynard Keynes, who argued that the animal spirits of entrepreneurs were an important determinant of investments and business cycles. These kind of models are often referred to as sunspot equilibria, because an essentially irrelevant factor may indeed move the economy if it works to coordinate agents' expectations. Azariadis (1981) consider the existence of sunspot equilibria within an overlapping generations setting, while Howitt and McAfee (1992) derive an animal-spirits cycle starting out from the multiple equilibria model of Diamond (1982). Farmer (2012) is a more recent version of this type of models, where market psychology plays an important role in selecting the equilibrium of the economy. Firms produce as many goods as are demanded, and the demand depends on self-fulfilling beliefs of market participants about the future value of assets.

\section{$7 \quad$ Inflation and output - the aggregate supply puzzle}

The relationship between inflation and output or unemployment constitutes a key part of most macroeconomic models. For decades, economists have used what is referred to as the standard aggregate supply schedule, based on the forward-looking overlapping contract models of Taylor (1980) and Calvo (1983). According to this model, firms set wages and/or prices in nominal terms for a certain period of time, on the basis of the expected prices of their competitors as well as the expected output level. When output is above the equilibrium level (i.e. a positive output gap), firms will want to set a higher price than their competitors, implying that the price growth increases. The upshot is a Phillips-curve type relation, where inflation is increasing in its two arguments expected inflation and the output gap:

$$
\pi_{\mathrm{t}}=\mathrm{E}_{\mathrm{t}} \pi_{\mathrm{t}+1}+\gamma\left(\mathrm{y}_{\mathrm{t}}-\mathrm{y}^{*}\right) \quad \gamma>0
$$

where $\pi_{\mathrm{t}}$ is the rate of inflation in period $\mathrm{t}, \mathrm{E}_{\mathrm{t}}$ is the expectations operator, $\mathrm{y}_{\mathrm{t}}$ is output, and $\mathrm{y}^{*}$ is equilibrium output.

However, as pointed out by Mankiw (2001), in spite of the theoretical foundation and its canonical position, the aggregate supply schedule is nevertheless inconsistent with evidence on several important aspects. Most importantly, (2) implies that inflation is expected to go down in a boom - according to (2) it is when $y_{t}-y^{*}>0$, that $\pi_{t}>E_{t} \pi_{t+1}$. This feature is inconsistent with evidence supporting the NAIRU, that inflation increases when output is high relative to the natural level. This is the main point of Ball (1994), who shows that the standard aggregate supply model as given by (2) implies that a credible disinflation should involve a boom, yet he provides evidence that disinflations usually are associated with a recession.

Many different attempts to reconcile theory and evidence have been proposed, involving various types of behavioral assumptions. An important and often used formulation is a hybrid model, where some agents are forward-looking and other agents are backward-looking (e.g. Gali \& Gertler, 1999). While this model clearly has attractive elements, it has also been 
heavily criticized as being inconsistent with evidence; specifically, the forward-looking part is said to be empirically invalid (Rudd \& Whelan, 2007; a response by Gali, Gertler and LopezSalido, 2005; Bårdsen and Nymoen, 2011).

Another possible explanation is based on a variation of the preferences of the agents (Fuhrer and Moore, 1995). However, as shown by Holden and Driscoll (2003), this approach has dubious micro foundations, as it requires that agents care about the wage others had in the past.

Other approaches emphasize the limits to the information that is available to the agents, and the limits to the ways they use this information. Ball (2000) suggests a model where agents use univariate forecasts, i.e. agents' forecasts are based solely on lagged inflation behavior. In contrast to the standard adaptive expectations assumption, this model allows agents' forecasts to depend on the stochastic properties of the variable. In historical periods when inflation was not persistent (as during the Gold standard), agents did not predict it to be persistent in the future. On the other hand, in the post-war period when inflation was persistent, agents expected it to continue being so. Thus, this approach has the virtue that it explains data for both time periods.

Another proposal is the "Sticky information" approach by Mankiw and Reis (2002), based on the assumption that agents update their information at intervals. This is a simple and attractive model that captures the notion that agents do not take all information into account immediately. Thus, firms may for some time change prices more mechanically without updating information, for then to make a more thorough revision based on updated information.

A third approach, suggested by Woodford (2003b) and Amato and Shin (2003), is based on the idea that there are limits to agents' ability of absorbing information. In these papers it is shown theoretically that noisy subjective perceptions by individual agents lead to greater uncertainty about higher-order expectations (i.e. what one agent expects other to expect about his expectations concerning their expectations, etc). One consequence of this feature is that inflation may be highly persistent. While this approach seems very promising, the complexity of the models has so far limited their use.

A fourth approach, suggested by Driscoll and Holden (2004), is that inflation persistence is a consequence of coordination problems under multiple equilibria. Following Bhaskar (1990), Driscoll and Holden assume that workers are concerned about fair treatment, in the sense that they care disproportionately more about being paid less than other workers than they do about being paid more than other workers. Driscoll and Holden show that wage setters' past behavior may work as an equilibrium selection device: among all the actions consistent with a possible equilibrium, agents expect other agents to play as they have played in the past. This focus on past actions can thus rationalize adaptive expectations, and therefore inertia in inflation, as a self-fulfilling prophecy, consistent with evidence on US post-war inflation. 


\section{$8 \quad$ Information and expectations}

Since the 1970s, rational expectations has been the main tool when economists were confronted with problems of information and expectations. Rational expectations, or, more appropriately, model-consistent expectations, implies a number of key assumptions:

- Agents know the model and the probability distributions for the stochastic variables

- Agents are able to calculate the equilibrium of the model, and believe that all other agents will choose equilibrium strategies.

It is widely acknowledged within the economics profession that these assumptions are often not realistic; many behavioral economists would say they almost never are. Agents have insufficient knowledge about the economic situation, and they have insufficient ability to understand it. In the literature, many different approaches have been proposed on how to deal with this.

In the learning literature (see Evans and Honkapohja, 2011, for a recent survey), the basic assumption is that agents do not know the full model, and/or that they are not able to form rational expectations. The agents observe the outcome, and update their expectations based on these observations (adaptive learning). An important result in the literature is that under many circumstances, the learning process may converge to the rational expectations equilibrium. In standard macroeconomic models, this will usually be the case provided that agents' environment remains stationary for sufficiently long time (Evans and Honkapohja, 2011).

However, under other circumstances, the outcome is more complex than under rational expectations. For example, Branch and Evans (2011) show that adaptive learning may lead to endogenous stock market bubbles and crashes. Evans and Honkapohja (2011) explore the link between monetary policy and private sector learning, and find that policy should be conditioned on private-sector expectations.

There are also a number of alternative approaches to problems with imperfect information. One formulation is the rational inattention idea of Sims (2003). Sims assumes that market players have limited capacities to process information, and that players choose how much information to acquire and process weighing the expected benefits against the costs of providing the information. Sims (2010) surveys recent work based on this idea. Two other interesting approaches, mentioned in section 7 above, is the sticky information idea of Mankiw and Reis (2002) and the limited ability to absorb information of Woodford (2003b) and Amato and Shin (2003).

A recent literature explores whether news about the economy may lead to business cycles. Jaimovich and Rebelo (2009) construct a model where good news about future technology may generate an economic expansion. The empirical model exhibits recessions that resemble those of the post war US economy. Milani (2011) explores whether expectational shocks may affect business cycle fluctuation, exploiting survey data on expectations. He finds that expectation shocks explain roughly half of business cycle movements. Surprisingly, the 
results indicate that the effect of expectations shocks is more persistent than the effect of structural demand shocks. Beaudry, Nam and Wang (2011) find that mood swings account for over 50 percent of business fluctuations in hours and output, and that these moods swings are strongly associated with long-run movements in total factor productivity. However, the results cannot tell whether the mood swings are a reflection of the future growth (as suggested by the news shock literature) or cause the future growth (as suggested by the self-fulfilling equilibrium literature).

In a series of papers, de Grauwe (2010a,b) advocates "bottom-up" macroeconomics, where it is explicitly taken into account that agents experience cognitive limitations. ${ }^{7}$ In the bottom-up model, agents use simple rules or heuristics to forecast future output and inflation. De Grauwe (2010b) considers two types of forecasting rules, one fundamentalist where expected output and inflation are equal to steady state levels, and one extrapolative, where expected output and inflation are equal to past levels. Agents evaluate their forecast performance, and if one rule performs better than the other, an increasing share of the population will use the better rule. The model has attractive features by generating inertia in output and inflation, and by allowing agents' sentiment to affect output: In periods where optimists, that is, agents who forecast a positive output gap, dominate, this will translate into above average output growth.

A number of studies have explored the effect of overconfidence, meaning that agents have excessive trust in the precision of the expectations. This form of bias has been documented e.g. by Griffin and Brenner (2004), and Biais, Hilton, Mazurier and Pouget (2005). Biais et al (2005) find that individuals who have greater judgmental overconfidence experience poorer trading performance in an experimental financial market. Holden and Kolsrud (1999) and Burnside, Han, Hirschleifer and Wang (2011) show that if investors overreact to recent information, this may explain the empirical puzzle of the forward premium bias. Jaimovich and Rebelo (2007) show that overconfidence may also increase business cycle volatility.

\section{$9 \quad$ Asset price bubbles}

One of the most contentious issues within financial economics has been the possible existence of bubbles in asset market. A bubble is a situation where the price of an asset is higher than the fundamental value, because the owners of the asset believe that they can sell at an even higher price at a later stage. Many economists have been skeptical to the existence of bubbles, partly because in most models with rational agents, bubbles cannot exist. In contrast, other economists argue that bubbles do exist, and find that this is an importance motivation for incorporating behavioral assumptions in macroeconomics.

\footnotetext{
${ }^{7}$ This is in contrast to standard macroeconomic models, called "top-down" models, where some or all agents are capable of understanding the whole picture and use this superior information to determine their optimal plans.
} 
In many cases rational behavior will prevent the possibility of a bubble. If the required rate of return on assets is higher than the growth rate of the economy, the market value of an asset bubble will sooner or later be greater than all other wealth in the economy, which is impossible. Rational agents will anticipate that the bubble will burst some time in the future, which will prevent the bubble from emerging. Note that this argument does not require that all agents are rational; a price bubble will involve the possibility of profitable arbitrage, so some agent will profit from selling the asset if the price is above equilibrium.

Most of the literature on asset bubbles is thus based on a behavioral foundation (see survey in Brunnermeier, 2009). As noted above, Branch and Evans (2011) explain bubbles within a model with adaptive learning. Agents are risk averse, and asset demand depends on their expectations of the mean and variance of stock market returns. Under adaptive learning, agents place greater emphasis on recent forecast errors, and occasional shocks may lead them to revise their risk estimates. This may affect the stock price so that subsequent revisions of the risk estimates place the economy onto a bubble-like path. The risk-estimate grows excessively along the bubble-path, paving the way for the eventual collapse of the demand for the risky asset, leading to a stock market crash.

Many studies with a behavioral foundation explain the existence of bubbles in settings with heterogeneous expectations. If some agents are better informed than others, the better informed may buy the asset in spite of a price above the fundamental value, because they expect to sell at a higher price to those who are less informed. Essentially, this is the "greater fool" idea discussed by Kindleberger (1978), that the last buyer was always counting on finding someone else to whom the stock or house could be sold.

Gilchrist, Himmelberg and Huberman (2005) emphasize that the combination of dispersion of investor beliefs and constraints on portfolio choice, e.g. on short selling, may lead to stock market bubbles. The authors find supporting empirical evidence, where increased dispersion leads to increased issuance of new equity as well as increased real investments.

Fuster, Laibson and Mendel (2010) propose a model with what they refer to as natural expectations, which is a weighted average between intuitive and rational expectations. Agents with natural expectations will overestimate persistence, inducing overreaction to news, and thus also excessive volatility in asset prices.

Asset bubbles may have important implications. The recent financial crisis provides a recent and stark example (see e.g. discussion in Akerlof and Shiller, 2009, and McDonald, 2009). Martin and Ventura (2011) argue that the crisis was due to a shock to investor sentiment that led to a collapse of a bubble or pyramid scheme in financial markets. Chirinko and Schaller (2011) explore whether bubbles in the stock market lead to overinvestment, using a panel data set of over 50000 firm-year observations from the US. The results indicate that firms with high stock price and poor investment opportunities accumulate between 15 and 45 percent too much capital, consistent with the hypothesis that bubbles affect economic activity by 
misallocating capital, consistent with the argument of e.g. Shiller (2005), and with the findings of Gilchrist et al (2005) referred to above.

As alluded to above, asset bubbles may also arise with rational agents. Blanchard and Watson (1982) propose a theory of rational bubbles in which agents' rational expectations are influenced in part by extrinsic random variables whose properties accord to historical bubble episodes. More recently, Bacchetta, Tille and van Wincoop (2012) show how "risk panic" may emerge also with rational agents, if expectations of increased volatility in the asset price leads to a reduction in the demand for the asset. In this case the negative expectation is fulfilled, involving a self-fulfilling negative feedback effect.

In some studies, seemingly irrational behavior can also be viewed as a sort of agency problem. Scharfstein and Stein (1990) show that herd behavior among managers may arise as a consequence of rational attempts by managers to improve their reputation as decision makers. Brunnermeier and Nagel (2004) find that hedge funds contributed to the dot com bubble. On a stock-by-stock basis, the hedge funds analyzed by Brunnermeier and Nagel started to cut back their holdings before prices collapsed, switching to technology stocks that still experienced rising prices. Thus, hedge fund managers captured the upturn, but avoided much of the downturn. Brunnermeier and Nagel conclude that this is consistent with hedge fund managers being able to predict some of the investor sentiment that was arguably behind the wild fluctuations in valuations of technology stocks at the time. An important insight from the study of Brunnermeier and Nagel (2004) concerns the limits of arbitrage: If close substitutes are unavailable, risk aversion among rational investors will make them much less aggressive.

A common argument among proponents of the economic man assumption is that agents learn from their errors, so that their behavior becomes closer to that predicted by the economic man assumption. This feature is documented in a recent study of sportscards transactions (List, 2004), where it is shown that inexperienced consumers' exhibit the endowment effect predicted by prospect theory, while consumers with intense market experience behave largely in accordance with neoclassical predictions (i.e. the economic man assumption). However, there are also important decisions, like buying a house, making a large financial investment and changing workplace, which most people take much less frequently. In a study of the Boston housing market, Genesove and Mayer (2001) show that potential sellers who were facing a considerable loss, asked for higher prices than otherwise identical sellers who had bought at a lower price, i.e. consistent with the loss aversion hypothesis. Asking for higher prices had a positive impact on the sales price, but it also reduced the likelihood that the house was actually sold. Furthermore, there is also considerable documentation that in many cases even the behavior of "professionals" deviate from the standard economic man assumptions, see e.g. Schleifer (2000). 


\section{Modifying the New Keynesian macroeconomic model}

Over the past 10-15 years, much of the research within core macroeconomics have used what is often referred to as the New Keynesian model, or the Dynamic Stochastic General Equilibrium model DSGE (see e.g. Clarida, Gali and Gertler, 1999; Woodford, 2003a). The basic framework consists of the neoclassical growth model, as suggested by Real Business Cycle theorists, where the key disturbance to the economy is an aggregate technology shock. The New Keynesian name refers to the fact that the model is extended to allow for price rigidities, implying that shocks to the economy, e.g. a temporary rise in productivity, will make the economy deviate from its flexible price equilibrium.

The DSGE model has obtained a remarkable position as the workhorse model for macroeconomic analysis. However, when the core DSGE model is confronted with evidence, it is clear that it has several shortcomings. In particular, there is too little inertia in the model, as compared to the empirical evidence. This has led to a large amount of research with the aim of improving the model, and much of it with a behavioral foundation.

The limited inertia of the model reflects that there is little inertia in the flex-price path of the economy, combined with the deviations from flex-price equilibrium usually being fairly short-lived. The deviations from the flex-price equilibrium reflect expectational errors and price rigidities, and these reasons are unlikely to explain long-lasting deviations.

The rather transitory and limited extent of deviations from equilibrium has several profound implications. First, it implies that there is little scope for economic policy. While monetary policy may affect aggregate demand via the determination of the short run nominal interest rate $^{8}$, the effect will not last longer than the deviation from the unique equilibrium level. Second, it implies that there is little scope for bubbles and financial instability. Bubbles of aggregate importance are bound to interact with aggregate output, and if aggregate output is tied down, there is less room for a bubble. Thus, in spite of the New Keynesian extensions, the key implications do not deviate much from the neoclassical benchmark.

As noted there has been a large amount of research with the aim of improving the model. Many of these innovations have a behavioral foundation. One example is habit formation in consumption see e.g. Smets and Wouters (2007) for a prominent application. Gali, Vallés and López-Salido (2007) extend the model by allowing for the presence of rule-of-thumb consumers, and shows that this changes the effect of increased government spending, which now turns out to be expansionary and thus consistent with empirical evidence. Another example is Mackowiak and Wiederholt (2011), who assume that decision makers have a limited amount of attention and thus must decide how to use it, as suggested in the rational

\footnotetext{
${ }^{8}$ A real effect of the nominal interest rate requires that nominal prices are not completely flexible, to prevent that a change in the nominal interest rate is offset by a instantaneous jump in the price level, and a subsequent change in the rate of inflation in parallel to the change in the nominal interest rate, so that the real rate of interest is unaffected by the monetary policy. Note that this condition is much weaker than the standard assumption where considerable price rigidity, e.g. Calvo-pricing, is usually imposed.
} 
inattention model of Sims (2003). Mackowiak and Wiederholt derive a mix of fast and slow responses of prices to shocks in line with empirical evidence.

There have also been non-behavioral modifications to the model, like the assumption of variable capital utilization (implying that capital owners may choose the utilization of the physical capital optimally so as to reduce the costs associated with depreciation), and everyperiod indexation of wages and prices to steady state inflation (to avoid distortions due to steady state inflation). Another way to improve the empirical fit has been to increase the number of exogenous shocks, allowing for e.g. shocks to the risk of entrepreneurs' activities, shocks to the discount rate in the household utility function, and a variety of technology shocks, see e.g. Christiano, Motto and Rostagno (2007).

The extensions of the model, both behavioral and non-behavioral, imply that the empirical explanatory power is much better, involving an apparent considerable ability of the model of accounting for the facts. Notably, in contrast to more empirically based models, like Bårdsen and Nymoen (2009), the DSGE model allows for accounting and explanatory exercises saying which economic mechanisms or shocks that drive the economic variables. While this property in principle is an advantage, it has also attracted critique. Chari, Kehoe and McGratten (2009) are critical to the assumption that the shocks in these models are structural, and they show that many of the model features, as well as their implications, are inconsistent with microeconomic evidence. A related criticism is voiced by Caballero (2010), who argue that "the so-called dynamic stochastic general equilibrium approach - has become so mesmerized with its own internal logic that it has begun to confuse the precision it has achieved about its own world with the precision it has about the real one. We are too far away from the absolute truth to be so specialized and to make the kind of confident quantitative claims that often emerge from the core."

\section{Concluding remarks}

In traditional macroeconomic theory, assumptions of rational behavior and rational expectations usually have several strong implications. Within fairly simple models, these assumptions will often pin down the outcome, leaving little room for other factors. As argued forcefully by Akerlof (2002) and Akerlof and Shiller (2009), this view is much too restrictive. The evidence provided by cognitive psychologists and behavioral economists strongly documents the existence of a number of important deviations from the economic man assumption. Furthermore, as also shown in the literature, the restrictive outcome is often also the result of very simple models, and much more complex outcomes are also possible under assumptions of complete rationality.

It is much more difficult to say what should come instead. There are so many effects and mechanisms that affect economic behavior and outcomes, and in most cases only a few can be taken into account in a satisfying way. This implies that there is severe competition for attention among the possible candidates. The literature is also still rather weak when it comes 
to distinguishing between different effects and mechanisms. Furthermore, the results of such tests are likely to be situation-specific, in the sense that an effect which dominates in one setting may be unimportant in another. It is also difficult to distinguish between behavioral and more "rational" explanations. For example, irrational investment decisions might be explained by irrational behavior among the investors, but it might also be a consequence of a inappropriate remuneration scheme for agents investing on behalf of others (see e.g. Rajan, 2005).

There are nevertheless some mechanisms and features that seem to be of crucial relevance. One of them is that fairness considerations affect wage setting and employment relationships. There is strong evidence that fairness considerations matter, and it seems to be of key importance for issues like wage rigidity and relative wages. Fairness considerations may interact with, and amplify, rigidities associated with labor market contracts, in particular concerning downward nominal wage rigidity. Such mechanisms are probably also relevant for the existence of and fluctuations in unemployment. An interesting finding in the literature is the large variation in the importance of fairness considerations, across individuals and depending on the specific setting. The large variation might be one reason why economists traditionally have neglected fairness considerations - after all, it is easy to find examples where fairness considerations do not seem to be of prime importance (e.g. the large wage and income differential between the bottom and the top in the distribution). The variation also complicates the analysis of policy implications.

Another important observation is that many people, and in some cases perhaps most or all people, are affected by the behavioral features discussed in section 2. Anchoring, framing, will-power problems and status quo biases are important features that affect how people behave. Thus, such features should be taken into account in the design of institutions, rules and regulations, e.g. when it comes to savings plans, consumer protection or the design of pension schemes, as discussed by Thaler and Sunstein (2008).

A third aspect is that in a complex situation, which often is the case in macroeconomics, agents are not able to solve for or predict the equilibrium outcome. Thus, a rational expectations outcome is only plausible if it is the result of a convergence of realistic behavior. The learning literature shows that this is may be the case if the circumstances are fairly stable, but it is less likely if large changes take place. Thus, there seems to be little reason to rule out the existence of large fluctuations or bubbles a priori.

A fourth and related aspect concerns the scope for sentiments and psychological factors, like optimism and pessimism. In the literature, such effects have been explained by behavioral features - direct assumptions on individual behavior - as well as arising from a multiplicity of equilibria or new information in models with more "rational" behavior. The vast uncertainty which exists about future trends and events provides room for large effects of fluctuations in agents' sentiment and expectations about the future. As expectations and sentiment both are affected by economic policy, such effects must also be taken into account in policy considerations. 
The financial crisis illustrates well both the multitude of effects and mechanisms that determine the macroeconomic outcome, as well as the potential huge effects. It is clear that the combination of ineffective regulation of the financial sector and distorted incentives among the agents working in this sector, contributed to the building up of large imbalances (see e.g. Plosser, 2010). However, it is also clear that distorted beliefs and excessive optimism were important (see e.g. Foote, Gerardi and Willen, 2012). Macroeconomic factors, like the easy access to credit, also contributed to the crisis, see Mian and Sufi (2009), just like it did during the boom and bust in farm land prices in the US in the 1920s (Rajan and Ramcharan, 2012).

What are the policy lessons? As noted above, some behavioral features have clear implications for institutional design, like pension schemes to prevent undersaving. In other cases the implications are much less clear. The economic downturn induced by the financial crisis is a case in point. On the one hand, there are plenty of explanations in the literature, both with behavioral and "rational" foundation, which lead to traditional Keynesian policy prescriptions, where countercyclical fiscal policy should be used to dampen the economic downturn. However, in extreme situations where a concern among private agents about increasing government debt is sufficiently important, one cannot rule out that the policy prescription may be turned (see Perotti, 2011, for a recent discussion of the evidence). There is strong reason to believe that the relative importance of the various effects will vary a lot depending on the specific circumstances. This could explain some of the large dispersion in the empirical literature regarding the effects of fiscal policy (see discussion in e.g. Auerbach, Gale and Harris, 2010).

On monetary policy some implications are clearer. There is in my view now strong reason to believe that monetary policy can have long-lasting effects on output in some situations, as suggested by the literature discussed in section 6 above. The recession following the financial crises illustrates that output may be considerably below potential for a long period, providing a considerable potential for stabilization policy. Central banks have more or less exploited this potential, dampening the recession, illustrating the importance of using monetary policy to stabilize the economy. Yet the recession also shows the limits to ex post stabilization, underscoring the importance of pursuing an economic policy in broader terms that reduces the risk of a financial crisis.

Where does this leave us? One important approach, which has attracted a lot of research recently, is to include behavioral features in standard macroeconomics models. This is clearly a highly promising route, as one may improve upon the existing theory by integrating more realistic behavioral assumptions. However, it should be done with care. Often, we do not know the correct specification of plausible behavioral features. As observed by Blanchard (2009), when a weak assumption has first been introduced, it may quickly become standard and be passed on from model to model with little discussion. There is risk that behavioral features in simple models might in fact capture inertia in data that in reality reflects other mechanisms, for example that the real world is much more complex, with many different firms trading with each other. Regrettably, we are still far away from knowing which 
approaches and assumptions that are appropriate (see Caballero, 2010, for a related view). Thus, there is need for more research to guide the choice of specification. However, as similar problems nevertheless are likely to persist, it also makes a strong case for trying many different approaches.

What other alternatives should be pursued? Some scholars argue that a more fundamental change is required, and that mainstream macroeconomic models are replaced with a new macroeconomic model based on a broader and more realistic framework, drawing upon insights from behavioral economics. De Grauwe (2010b) is a recent attempt of this. So called "agent based" models, see e.g. Lebaron and Tesfatsion (2008) is a further step away from the standard theory, which nevertheless seems like a promising avenue for future research, as it may allow us to explore the implications of much more complicated models and settings than we would otherwise be able to. Also more empirically oriented, estimated models as discussed in Bårdsen and Nymoen (2009) are valuable, both by being a benchmark for evaluation of other theories and empirical applications, and for providing independent information about how the economy works. Bårdsen, Reijer, Jonasson and Nymoen (2012) show that such models may be useful for forecasting and policy analysis. Finally, economists should also to a greater extent use other types of information, like case studies and lessons from historical episodes. For example, Reinhart and Rogoff (2009) show the considerable similarity between financial crises over the centuries, providing a knowledge which makes it easier to detect danger signals at an early stage.

\section{References:}

Abel, A. B. (1990). Asset Prices under Habit Formation and Catching up with the Joneses. American Economic Review (Papers and Proceedings), 80(2), pp. 38-42.

Ainslie, G. (1992). Picoeconomics: The Interaction of Successive Motivational States within the Individual. Studies in Rationality and Social Change. Cambridge: Cambridge Univ. Press.

Ainslie, G, and N. Haslam (1992). Hyperbolic discounting. In G. Loewenstein and J. Elster (eds). Choice over time. New York: Russell Sage, 57-92.

Akerlof GA. 1982. Labor contracts as partial gift exchange. Quarterly Journal of Economics 97, 543-69

Akerlof, G. (1984). Gift exchange and efficiency wage theory: four views. American Economic Review Papers and Proceedings 74, 79-83.

Akerlof, G. (2002). Behavioral Macroeconomics and Macroeconomic Behavior. American Economic Review 92(3): 411-433.

Akerlof, George. A.( 2007). The Missing Motivation in Macroeconomics. American Economic Review 97(1): 5-36. 
Akerlof G.A, Dickens WT, Perry WL (1996). The macroeconomics of low inflation. Brookings Papers on Economic Activity 1, 1-75.

Akerlof G.A, Dickens WT, Perry WL. (2000). Near rational wage and price setting and the long run Phillips curve. Brookings Papers on Economic Activity 1, 1-60.

Akerlof, G.A. and R.J. Shiller (2009). Animal spirits. Princeton: Princeton University Press. Akerlof GA, Yellen JL. 1990. The fair wage-effort hypothesis and unemployment. Quarterly Journal of Economics 105, 255-83

Alessie, R. And F. Teppa (2010). Saving and habit formation: evidence from Dutch panel data. Empirical Economics 38, 385-407.

Amato, J. D and H.S. Shin (2003). Public and private information in monetary policy models. Mimeo, London School of Economics.

Andersen, S. G.W. Harrison, M. Lau and E. E. Rutström (2011). Discounting behavior: A reconsideration. Mimeo, Department of Economics, Copenhagen Business School.

Auerbach, A.J., W.G. Gale, and B.H. Harris (2010). Activist fiscal policy. Journal of Economic Perspectives 24, 4, 141-164.

Azariadis, C. (1981). Self fulfilling prophecies. Journal of Economic Theory 25, 380-396.

Bacchetta, P, E. van Wincoop, and C. Tille (2012). Self-fulfilling risk panics. Forthcoming in American Economic Review.

Ball, L. S. (1994). Credible Disinflation with Staggered Price Setting. American Economic Review, 84(1):282-289.

Ball, L.S. (1999). Aggregate demand and long-run unemployment, Brookings panel on economic activity, September.

Ball, L S. (2000). Near-Rationality and Inflation in Two Monetary Regimes. NBER Working Paper 7988.

Bauer, T., H. Bonin, L. Goette, and U. Sunde (2007). Real and nominal wage rigidities and the rate of inflation: evidence from West German micro data. The Economic Journal 117, F508-F529.

Beaudry, P, D. Nam and J. Wang (2011). Do mood swings drive business cycles and is it rational? NBER working paper 17651.

Bénabou, R. and J. Tirole (2004). Willpower and personal rules. Journal of Political Economy $112,4,848-886$. 
Benhabib, J. and R. E.A. Farmer (1994). Indeterminacy and increasing returns. Journal of Economic Theory 63, 1, 19-41.

Benhabib, J., A. Bisin, and A. Schotter. (2010). Present-bias, quasi-hyperbolic discounting, and fixed costs. Games Economic Behavior 69, 205-223

Bewley, T.F. (1999). Why wages don't fall during a recession. Harvard University Press.

Bhaskar, V. (1990). "Wage relatives and the natural range of unemployment." Economic Journal 100, 60-66.

Biais, B., D. Hilton, K. Mazurier. and S. Pouget (2005). Judgemental Overconfidence, SelfMonitoring, and Trading Performance in an Experimental Financial Market. Review of Economic Studies 72, 287-312.

Blanchard, O.J. (2009). The state of macro. Annual Review of Economics 1, 209-228.

Blanchard, O. and M. Watson. (1982). Bubbles, rational expectations, and financial markets. In Crises in the economic and jnancial structure, ed. Paul Wachtel. Lexington, Mass.: Lexington.

Bowles, S. (1998). Endogenous preferences: The cultural consequences of markets and other economic institutions. Journal of Economic Literature XXXVI: 75-111.

Branch, W.A. and G.W. Evans (2011). Learning about risk and return: A simple model of bubbles and crashes. American Economic Journal: Macroeconomics forthcoming.

Brown M, Falk A, Fehr E. (2004). Relational contracts and the nature of market interactions. Econometrica 72, 747-80

Browning, M. and M.D. Collado (2001). The response of expenditures to anticipated income changes. Panel data estimates. American Economic Review 91 (3), 681-692.

Brunnermeier, M. (2009). Bubbles. Entry in The New Palgrave Dictionary of Economics, edited by Steven Durlauf and Lawrence Blume, 2nd edition.

Brunnermeier, M. og S. Nagel (2004). Hedge funds and the technology bubble. Journal of Finance 59(5), 2013-2040.

Burger, N, G. Charness, and J. Lynham (2009). Field and online experiments on procrastination and willpower. Mimeo, Rand corporation.

Burks, SV, J.P Carpenter, L. Goette and A. Rustichini. (2009). Is overconfidence a judgment bias? Theory and evidence. Mimeo, University of Geneva.

Burnside, C., B. Han, D. Hirshleifer, and T.Y Wang (2011). Investor overconfidence and the forward premium puzzle. Review of Economic Studies 78, 523-558. 
Bårdsen, G. and R. Nymoen (2009). Macroeconomic modelling for policy. Palgrave Handbook of Econometrics vol 2, Ch 17, T. C. Mills and K. Patterson (eds). Palgrave MacMillan.

Bårdsen, G., A. den Reijer, P. Jonasson, and R. Nymoen (2012). MOSES: Model for studying the economy of Sweden. Forthcoming in Economic Modelling.

Caballero, R.J. (2010). Macroeconomics after the crisis: Time to deal with the pretense-ofknowledge syndrome. Journal of Economic Perspectives 24, 4, 85-102.

Calvo, G (1983). Staggered Prices in a Utility-Maximizing Framework."Journal of Monetary Economics 12(4):983-998.

Campbell, John Y. and Deaton, Angus S. (1989). Why Is Consumption So Smooth? Review of Economic Studies 56(3), 357-73.

Campbell, J.Y., N.G. Mankiw. (1990) 'Permanent income, current income, and consumption. Journal of Business and Economic Statistics 8 (3), 265-279.

Card D, Krueger A. 1994. Minimum wages and employment: a case study of the fast-food industry in New Jersey and Pennsylvania. American Economic Review 84, 772-793.

Chari, V.V, P.J. Kehoe, and E.R. McGrattan (2009). New Keynesian models: Not yet useful for policy analysis. American Economic Journal: Macroeconomics 1, (1), pp. 242-266.

Chirinko, R.S. and H. Schaller (2011). Do bubbles lead to overinvestment? A revealed preference approach. CESifo working paper 3491.

Choi, J.J., D. Laibson, and B.C. Madrian (2011). \$100 bills on the sidewalk: Suboptimal investment in 401(k) plans. The Review of Economics and Statistics 93, 748-763.

Christiano, L., R. Motto, and M. Rostagno (2007). Shocks, structures or monetary policies? The Euro area and the US after 2001. ECB working paper 774.

Clarida, R. J. Galí, M. Gertler (1999). The Science of Monetary Policy: A New Keynesian perspective. Journal of Economic Literature XXXVII (December), 1661-1707.

Constantinides, G.M (1990). Habit Formation: A Resolution of the Equity Premium Puzzle. Journal of Political Economy 98(3), 519-43.

Diamond, P. (1982). Aggregate demand management in search equilibrium. Journal of Political Economy 90, 881-894.

Dickens, W., L. Goette, E.L. Groshen, S. Holden, J. Messina, M.E. Schweitzer, J. Turunen, and M. Ward (2007). How Wages Change: Micro Evidence from the International Wage Flexibility Project. Journal of Economic Perspectives 21(2), 195-214. 
De Bondt, W.F. and R.H. Thaler (1985). Does the stock market overreact?. Journal of Finance 40, 793-805.

De Grauwe, P. (2010a). Top-down versus bottom-up macroeconomics. CESifo Economic Studies 56(4), 465-497.

De Grauwe, P. (2010b). Behavioral macroeconomics. Manuscript, University of Leuven.

Driscoll, J C. and S Holden (2004). Coordination, Fair Treatment and Inflation Persistence. Journal of European Economic Association 2, (2-3), Papers and Proceedings, 240-251

Dynan, Karen. E. 2000. "Habit Formation in Consumer Preferences: Evidence from Panel Data." American Economic Review, 90(3): 391-406.

Evans, G.W. and S. Honkapohja (2011). Learning as a rational foundation for macroeconomics and finance. CEPR Discussion Paper 8340.

Falk A, E. Fehr, C. Zehnder(2006) Fairness perceptions and reservation wages - the behavioral effects of minimum wage laws. Quarterly Journal of Economics 121, 1347-81

Farmer, R. E. A (2012). Confidence, crashes and animal spirits. The Economic Journal 122, 155-172.

Fehr E, M. Brown, C. Zehnder (2009). On reputation: a microfoundation of contract enforcement and price rigidity. Economic Journal 119, 333-53

Fehr, E., L. Goette, and C. Zehnder (2009). A behavioral account of the labor market: The role of fairness concerns. Annual Review of Economics, 1, 355-384.

Fehr E, G. Kirchsteiger, and A. Riedl (1993). Does fairness prevent market clearing? An experimental investigation. Quarterly Journal of Economics 108, 437-60

Fehr, E and K M. Schmidt (2002). Theories of Fairness and Reciprocity- Evidence and Economic Applications. In: M. Dewatripont, L. Hansen and St. Turnovsky (Eds.), Advances in Economics and Econometrics - 8th World Congress, Econometric Society Monographs, Cambridge, Cambridge University Press.

Foote, C.L., K.S. Gerardi, and P.S. Willen (2012). Why Did So Many People Make So Many Ex Post Bad Decisions? The Causes of the Foreclosure Crisis. Federal Reserve Bank of Boston Discussion Paper 12-2.

French, S., K. Kubo, and D. Marsden (2002)Why does performance pay de-motivate: financial incentives versus performance appraisal In: Hanami, Tadashi, (ed.) Universal wisdom through globalisation: selected papers from the 12th IIRA world congress, Tokyo. Japan Institute of Labour Report (9). Japan Institute of Labour, Tokyo, Japan.

Fuhrer, J. (2000). Habit formation in consumption and its implications for monetary-policy models. American Economic Review 90(3): 367-390. 
Fuhrer, J and G Moore (1995). Inflation persistence. Quarterly Journal of Economics ,CX,: 127-160.

Fusaro, M.A., Dutkowsky, D.H. (2011) What explains consumption in the very short-run?

Evidence from checking account data. Forthcoming in Journal of Macroeconomics

Fuster, A., D. Laibson, and B. Mendel (2010). Natural expectations and macroeconomic fluctuations. Journal of Economic Perspectives 24, 4, 67-84.

Gali, J. and M. Gertler (1999). "Inflation Dynamics: A Structural Econometric Analysis." Journal of Monetary Economics 44, 195-222.

Gali, J., M. Gertler and J.D. Lopez-Salido. (2005). Robustness of the estimates of the hybrid new Keynesian Phillips curve. Journal of Monetary Economics 52, 1107-1118.

Gali, J. Vallés and J.D. López-Salido (2007). Understanding the effects of government spending on consumption. Journal of European Economic Association 5(1), 227-270.

Genesove, D., and C. Mayer (2001). Loss aversion and seller behavior: evidence from the housing market. Quarterly Journal of Economics 116:1233-1260.

Gilchrist, S., C.P. Himmelberg, G. Huberman (2005). Do stock price bubbles influence corporate investment? Journal of Monetary Economics 52, 805-827.

Griffin, D. and I. Brenner (2004). Perspectives on Probability Judgment Calibration. In Koehler, D. J. and Harvey, N. (eds) Blackwell Handbook of Judgment and Decision Making (Malden: Blackwell Publishing) 177-199.

Hall, R.E. (2005). Employment Fluctuations With Equilibrium Wage Stickiness. American Economic Review 95, 50-65.

Holden, S. (1994). Wage bargaining and nominal rigidities, European Economic Review 38, 1021-1039.

Holden, S. and J. Driscoll (2003). Inflation persistence and relative contracting. American Economic Review 93, 1369-1372.

Holden, S. and D. Kolsrud (1999). Noisy signals in target zone regimes: Theory and Monte Carlo experiments. European Economic Review 43, 1531-1567.

Holden, S. and F. Wulfsberg (2009). How strong is the macroeconomic case for downward real wage rigidity? Journal of Monetary Economics 56, 605-615.

Howitt, P. And P. McAfee (1992). Animal spirits. American Economic Review 82 (3), 493507

Hsieh, C-T. (2003). Do Consumers React to Anticipated Income Changes? Evidence from the Alaska Permanent Fund. American Economic Review 93, 397-405. 
Jaimovich, N. and S. Rebelo (2007). Behavioral theories of the business cycle. Journal of European Economic Association, 5 (2-3), 361-368.

Jaimovich, N. and S. Rebelo (2009). Can News about the Future Drive the Business Cycle? American Economic Review , 1097-1118.

Jappelli, T. and L. Pistaferri (2010). The consumption response to income changes. Annual Review of Economics 2, 479-506.

Kahneman, D. and A. Tversky (1979). Prospect Theory: An Analysis of Decision under Risk. Econometrica 47, 263-291.

Kahneman, D., J.K. Knetsch, and R. Thaler (1986). Fairness as a Constraint on Profit Seeking: Entitlements in the Market The American Economic Review 76 ( 4), 728-741.

Keynes, J.M. (1936). The General Theory of Employment, Interest and Money. London: MacMillan.

Kindleberger, C. (1978). Manias, Panics, and Crashes: A History of Financial Crises, New York: Basic Books.

Krueger, AB and A. Mas (2004). Strikes, scabs, and tread separations: labor strife and the production of defective Bridgestone/Firestone tires. Journal Political Economy 112, 253-289.

Laibson, D. (1997). Golden Eggs and Hyperbolic Discounting. Quarterly Journal of Economics 62, 443-477.

Laibson, D, A Repetto, and J Tobacman (2003). “A debt puzzle”. In P Aghion, R Frydman, J Stiglitz and M Woodford (eds). Knowledge, Information, and Expectations in Modern Macroeconomics: In Honor of Edmund S Phelps. Princeton: Princeton University Press.

Laibson, D. (2009). Comment on Household saving behavior in the United States: The role of literacy, information and financial education program. In Policymaking Insights from Behavioral Economics. C. Foote, L. Goette, and S. Meier (eds). Federal Reserve Bank of Boston.

LeBaron, B. and Leigh Tesfatsion (2008). Modeling Macroeconomies as Open-Ended Dynamic Systems of Interacting Agents. American Economic Review (Papers \& Proceedings), 98 (2), 246-250.

List, J.A. (2004). Neoclassical Theory Versus Prospect Theory: Evidence from the Marketplace. Econometrica 72(2), 615-625.

Ljungqvist, L. and H. Uhlig (2000). Tax policy and aggregate demand management under catching up with the Joneses. American Economic Review 90(3): 356-366.

Loewenstein, G. and D. Adler (1995). A bias in the prediction of tastes. The Economic Journal 105, 929-937. 
Lusardi, A. (2009). Household saving behavior in the United States: The role of literacy, information and financial education program. In Policymaking Insights from Behavioral Economics. C. Foote, L. Goette, and S. Meier (eds). Federal Reserve Bank of Boston.

Lye, J.N., I.M. McDonald and H. Sibly (2001). An estimate of the range of equilibrium rates of unemployment for Australia. Economic Record 77 (236), March, 35-50.

MacLeod, W.B. and J.M. Malcomson (1993). Investment, holdup, and the form of market contracts. American Economic Review 37, 343-354.

Madrian, B.C. and D.F. Shea (2001). The power of suggestion. Inertia in 401(k) participation and savings behavior. Quarterly Journal of Economics 116, 4, 1149-1187.

Mackowiak, B. and M. Wiederholt (2011). Business cycle dynamics under rational inattention. ECB working paper 1331.

Mankiw, N. Gregory (2001). The Inexorable and Mysterious Tradeoff Between Inflation and Unemployment.. Economic Journal 111.: C45-61.

Mankiw, N.G. and R. Reis (2002). Sticky information versus sticky prices: A proposal to replace the New Keynesian Phillips curve. Quarterly Journal of Economics 117, 1295-1328.

Martin, A. and J. Ventura (2011). Theoretical notes on bubbles and the current crisis. ECB working paper 1348 .

Mas, A. (2008). Labor unrest and the quality of production: evidence from the construction equipment resale market. Review of Economic Studies 75, 229-258.

Mian, A. and A. Sufi (2009). The consequences of mortgage credit expansion. Evidence from the U.S. mortgage default crisis. Quarterly Journal of Economics 124, (4), 1449-1496.

McDonald, I. M. (2009). The global financial crisis and behavioural economics. Economic Papers 28, 249-254.

Milani, F. (2011). Expectation shocks and learning as drivers of the business cycle. Economic Journal 121, 379-401.

Perotti, R. (2011). The austerity myth: Gain without pain. Mimeo, IGIER.

Phelps, E.S. and R. A. Pollak (1968). On Second-best National Savings and Gameequilibrium Growth. Review of Economic Studies, 35, 185-199

Plosser, C.I. (2010). Good intentions, bad incentives and ugly results. Speech October 20, Federal Reserve Bank of Philadelphia.

Pollak, R (1970). Habit formation and dynamic demand function. Journal of Political Economy 78, 745-763. 
Pissarides, C. (2009). The unemployment volatility puzzle: Is wage stickiness the answer? Econometrica 77, 5, 1339-1369.

Rabin, M. (1998). Psychology and economics. Journal of Economic Literature XXXVI: 11-46.

Rabin, M (2003), The Nobel memorial prize for Daniel Kahneman, Scandinavian Journal of Economics 105 (2), 157-180.

Rajan, R. G. (2005): Has financial development made the world riskier? Mimeo, IMF.

Rajan, R. and R. Ramcharan (2012). The anatomy of a credit crisis. The boom and bust in farm land prices in the US in the 1920s. Mimeo, Chicago Booth.

Reinhart, C.M. and K.S. Rogoff (2009). This time is different. Eight centuries of financial folly. Princeton University Press.

Rubinstein, A. (2003). Economics and Psychology? The Case of Hyperbolic Discounting, International Economic Review 44, 1207-1216.

Rudd, J. and K. Whelan (2007). Modeling inflation dynamics: A critical review of recent work. Journal of Credit and Banking, 39 (2), 155-170.

Scharfstein, D.S. and J.C. Stein (1990. Herd behavior and investment. American Economic Review 80 (3), 465-479.

Shafir, E., P.A. Diamond, and A.Tversky (1997). On Money Illusion. Quarterly Journal of Economics 112 (2), 341-374

Shapiro, C. and J.E. Stiglitz (1984). Equilibrium Unemployment as a Discipline Device. American Economic Review 74, 433-444.

Shelling, T. (1984). Self-Command in Practice, in Policy, and in a Theory of Rational Choice. American Economic Review vol. 74(2), 1-11.

Shiller, R.J. (2005). Irrational Exuberance. Princeton: Princeton University Press.

Shimer, R. (2005). The cyclical behavior of equilibrium unemployment and vacancies. American Economic Review 95, 25-49.

Shleifer, A. (2000). Inefficient Markets: An Introduction to Behavioral Finance. Oxford: Oxford University Press.

Sims, C. (2003). Implications of rational inattention. Journal of Monetary Economics 50(3), 665-690.

Sims, C. (2010). Rational inattention and monetary economics. Forthcoming in Handbook of Monetary Policy Elsevier. 
Smets, F. and R. Wouters (2007). Shocks and frictions in US business cycles: A Bayesian DSGE approach. American Economic Review 97, 586-606.

Taylor, J. (1980). Aggregate dynamics and staggered contracts. Journal of Political Economy LXXXVIII, 1-24.

Thaler, R. H. and S. Beneratzi (2004). Save Tomorrow ${ }^{\text {TM}: ~ U s i n g ~ B e h a v i o r a l ~ E c o n o m i c s ~ t o ~}$ Increase Employee Saving. Journal of Political Economy 112, 164-187.

Thaler, R. H. and C. R. Sunstein (2008). Nudge: Improving Decisions About Health, Wealth, and Happiness. Yale University Press.

Tobin, J. (1972). Inflation and unemployment. American Economic Review 62(2), 1-18.

Tversky, A. and D. Kahneman (1991). Loss aversion in riskless choice: A referencedependent model. Quarterly Journal of Economics 106, 1039-1061.

Woodford, M (2003a). Interest and Prices. Princeton: Princeton University Press.

Woodford, M. (2003b). Imperfect common knowledge and the effects of monetary policy. In P. Aghion, R. Frydman, J. Stiglitz and M. Woodford (eds). Knowledge, Information, and Expectations in Modern Macroeconomics: In Honor of Edmund S Phelps. Princeton:

Princeton University Press. 
Publisher: Hans-Böckler-Stiftung, Hans-Böckler-Str. 39, 40476 Düsseldorf, Germany Phone: +49-211-7778-331, IMK@boeckler.de, http://www.imk-boeckler.de

IMK Working Paper is an online publication series available at: http://www.boeckler.de/imk 5016.htm

ISSN: $1861-2199$

The views expressed in this paper do not necessarily reflect those of the IMK or the Hans-Böckler-Foundation.

All rights reserved. Reproduction for educational and non-commercial purposes is permitted provided that the source is acknowledged. 